Łukasz CZYŻ ${ }^{1}$, Jarosław GNAT ${ }^{2}$, Damian KOLNY ${ }^{3}$

Opiekun naukowy: Dariusz PLINTA ${ }^{4}$

DOI: https://doi.org/10.53052/9788366249844.05

\title{
ANALIZA POTENCJALU ZASTOSOWANIA TECHNOLOGII WIRTUALNEJ RZECZYWISTOŚCI W PROJEKTOWANIU ZAKŁADÓW PRZEMYSŁOWYCH
}

\begin{abstract}
Streszczenie: Niniejszy artykuł opisuje dokonujący się postęp technologiczny w zakresie wirtualizacji świata rzeczywistego, który coraz bardziej znajduje zastosowanie w przemyśle. Intencją autorów jest zwrócenie uwagi na dokonujący się rozwój w zakresie możliwości wsparcia projektowania konstrukcji hal przemysłowych i organizacji ich przestrzeni produkcyjnych. Współczesne możliwości technologiczne pozwalają przekroczyć horyzont dotychczasowej wizualizacji rezultatów projektowych i wejść w wirtualną interakcję z nimi.
\end{abstract}

Słowa kluczowe: wirtualna rzeczywistość, analiza potencjału technologii, projektowanie zakładów przemysłowych, wizualizacja projektowa, cyfrowa fabryka

\section{POTENTIAL ANALYSIS OF AN IMPLEMENTATION VIRTUAL REALITY TECHNOLOGY IN TERMS OF INDUSTRIAL PLANTS DESIGNING}

\footnotetext{
Summary: The article presents the technological advances in real-world virtualization, which are increasingly being used in industry. Authors intention is to pay attention to ongoing progress in terms of the possibility to support the designing of construction industrial halls and the organization of their workplaces. Modern technological possibilities allows to exceed the horizon of the current visualization projected results and step into virtual interaction inside of it.

Keywords: virtual reality, technology potential analysis, industrial plants designing, project visualization, digital twin

1 Akademia Techniczno-Humanistyczna w Bielsku-Białej, Wydział Budowy Maszyn i Informatyki, lukczy2014@onet.pl

2 inż., Akademia Techniczno-Humanistyczna, Wydział Budowy Maszyn i Informatyki, gnat.jaroslaw@gmail.com

${ }^{3}$ mgr inż., Akademia Techniczno-Humanistyczna w Bielsku-Białej, Wydział Budowy Maszyn i Informatyki, dkolny@ath.bielsko.pl

${ }^{4}$ dr hab. inż., prof. ATH, Akademia Techniczno-Humanistyczna w Bielsku-Białej, Wydział Budowy Maszyn i Informatyki, dplinta@ath.bielsko.pl
} 


\section{Wprowadzenie}

W ciągu stuleci na świecie wielokrotnie dochodziło do przełomowych osiągnięć technologicznych, które przyczyniły się do rozwoju gospodarczego i społecznego wielu krajów, wywołując tym samym tzw. rewolucje przemysłowe. Historia przemysłu określa, że pierwsze dwie rewolucje przemysłowe związane były z mechanizacją i elektryfikacją procesów produkcyjnych. W latach 70. XX wieku w wyniku wdrożenia częściowej automatyzacji procesów produkcyjnych, związanej z zastosowaniem zaawansowanej elektroniki i technologii informacyjnych, doszło do trzeciej rewolucji przemysłowej. W 2011 roku w Niemczech po raz pierwszy zaprezentowano koncepcję Przemysłu 4.0, nazywanego również czwartą rewolucją przemysłową. Czwarta rewolucja przemysłowa związana jest z zaawansowaną transformacją technologiczną, która stanowi połączenie nowoczesnych technologii i interakcji cyberfizycznych. Wprowadzenie koncepcji Przemysłu 4.0 do przedsiębiorstw pociąga za sobą szeroko pojmowaną zmianę sposobu ich funkcjonowania oddziałującą nie tylko na produkt, ale również na cały łańcuch wartości, realizowane procesy i otoczenie. Jednym z najważniejszych wyzwań dla produkcji w ramach czwartej rewolucji przemysłowej jest połączenie przestrzeni fizycznej ze światem cyfrowym. Technologią, która umożliwia taką integrację, jest cyfrowy bliźniak (ang. Digital Twin - DT). To model symulacyjny systemu mogący reprezentować unikalny zasób - maszynę, proces, a nawet fabrykę, który jest odwzorowaniem geometrii takiego obiektu, ale także jego cech i zachowań. Tego typu nowoczesne podejście w cyfryzacji świata rzeczywistego wspierane jest przez rozwój zaawansowanych i zintegrowanych systemów połączonych z rzeczywistością rozszerzoną (ang. Augmented Reality - AR) i wirtualną (ang. Virtual Reality - VR) umożliwiając prowadzenie badań mających na celu przewidzenie rezultatów różnych scenariuszy przed wprowadzeniem przełomów technologicznych. Symulacja jest wykorzystywana w wielu aspektach działania przedsiębiorstwa i stanowi kluczowy czynnik dla rozwoju Przemysłu 4.0, m.in. dzięki analizie różnych wariantów procesu bez wpływu na jego przebieg w czasie rzeczywistym oraz tworzenie i analizę scenariuszy z uwzględnieniem przewidywanych zmian w przyszłości. [3]

Celem artykułu jest przedstawienie analizy potencjału i możliwości zastosowania technologii wirtualnej rzeczywistości w obszarze projektowania zakładów przemysłowych. Wykorzystanie tego typu nowoczesnej technologii jest podejściem innowacyjnym dla większości przedsiębiorstw, lecz wymaga szerszej i zaawansowanej analizy w kontekście właściwego momentu i sposobu wdrożenia.

\section{Wirtualna Rzeczywistość - VR}

Wirtualna rzeczywistość to trójwymiarowy obraz stworzony przy wykorzystaniu technologii informatycznej. Za pomocą konkretnej jednostki obliczeniowej kreuje się przedmioty, przestrzenie, zdarzenia, które mogą imitować obiekty rzeczywiste jak i fikcyjne. Do obsługi wirtualnej rzeczywistości wewnątrz projekcji potrzebne są kontrolery (zazwyczaj dwa - po jednym na każdą dłoń) z wbudowanymi czujnikami i przyciskami (alternatywnie mogą to być również specjalne kombinezony odwzorowujące ruch całego ciała). Kluczowymi elementami całego zestawu są tzw. „latarnie” - dwa czujniki na podczerwień ustawione po przeciwnych stronach tak, aby wytyczały i lokalizowały przestrzeń, w której może poruszać się użytkownik oraz 
wykrywały ruch kontrolerów. Do obsługi sprzętu potrzebna jest stacja obliczeniowa posiadająca odpowiednią moc do uruchomienia wirtualnej projekcji. Wymagania stawiane przed takim sprzętem mogą się różnić $w$ zależności, od jakości wyświetlanego obrazu. Najważniejszą rolę w tworzeniu takiego zespołu stanowi karta graficzna. Większość producentów w rekomendowanym zestawie stosuje kartę NVIDIA GTX 1060, co stanowi średnią półkę cenową i wydajność na zadawalającym poziomie. Jeśli użytkownik oczekuje od wirtualnej rzeczywistości najwyższej jakości obrazu, to znajdzie na runku okulary obsługujące rozdzielczość $8 \mathrm{~K}$, co tak naprawdę stanowi dwa wyświetlacze $4 \mathrm{~K}$, po jednym na oko. Wówczas wymagana wydajność podzespołów rośnie, a wraz z nią cena poszczególnych komponentów.

Pierwszym urządzeniem, które posiadało najbardziej zbliżone odczucia do zamknięcia się w świecie wirtualnym, było urządzenie „SENSORAMA" opatentowane w roku 1962. Można je uznać za swoiste wprowadzenie i zaprezentowanie produktu VR na rynku. Urządzenie nie odniosło sukcesu ze względu na zbyt duże koszty tworzenia obrazu 3D dla użytkownika, co jest typowe dla nowo ukazanych technologii. W kolejnych latach na potrzeby wojskowe zostały opracowane również gogle VR, które pozwoliły użytkownikowi na realne odwzorowanie ruchów głowy i podążanie oczyma za obrazem. Zostały również wprowadzone odpowiednie kontrolery i kombinezony, które mogły odwzorować ruchy kończyn. Dodatkowo obraz przestał być kręcony poprzez kamery 3D, a zaczęto generować widok przy pomocy komputera. Opracowano również możliwość przebywania więcej niż jednej osoby w świecie wirtualnym, całość była głównie używana do gier wideo. Cały sprzęt jeszcze przez długi czas był drogi, duży i ciężki. Dopiero od roku 1995 zaczęły pojawiać się urządzenia i rozwiązania VR dostępne dla szerszego grona użytkowników, w rozmiarach umożliwiających swobodne używanie produktu również $\mathrm{w}$ domowych warunkach, a także w cenie osiągalnej dla większej części społeczeństwa. [11]

Z założenia wirtualna rzeczywistość ma wywoływać naturalne i realne doznania, do niedawna wykorzystywana głównie w grach komputerowych, odgrywa coraz większą rolę także w innych dziedzinach życia.

\section{Analiza potencjału technologii VR}

Wirtualna rzeczywistość zyskuje na znaczeniu i znajduje praktyczne zastosowanie w wielu różnych branżach. Jak każda nowa technologia, nim znajdzie doraźne zastosowanie w przemyśle, musi przejść właściwą ścieżkę rozwoju i weryfikacji przez wewnętrzne i zewnętrzne środowisko, które ją kształtuje. Sytuacja ta doskonale jest przedstawiana przez tzw. cykl popularności wschodzących technologii albo inaczej „Krzywej Gartnera” (rys. 1). Według założeń merytorycznych cyklu Gartnera, każda technologia przechodzi przez określone fazy rozwoju i oczekiwań, jakie stawia przed nią rynek. Fazy te są podobne dla każdej technologii, chociaż długości ich trwania mogą się zasadniczo różnić. Część technologii nigdy nie osiąga etapu określanego „płaskowyżem produktywności” (stosowanie danej technologii w codziennych procesach wytwórczych), np. stając się przestarzałymi, zanim osiągną dojrzałość. 


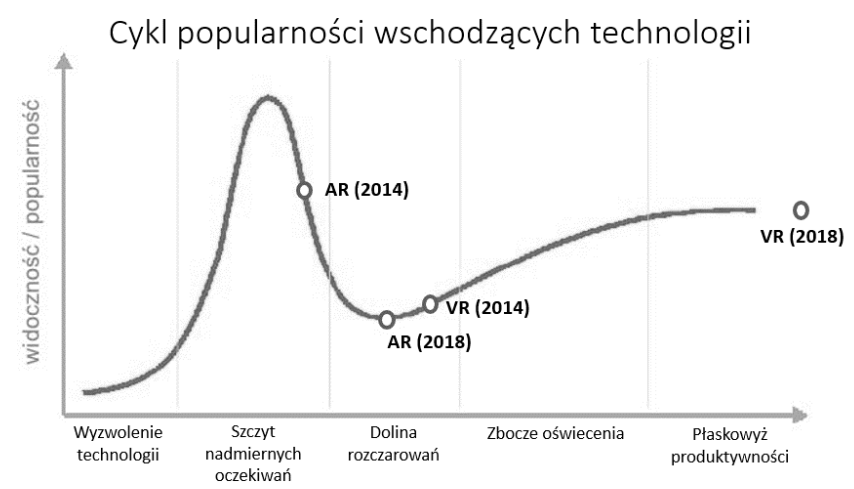

Rysunek 1. Krzywa popularności dla technologii VR i AR (2014-2018)

Na powyższym wykresie przebiegu popularności technologii VR i AR zaobserwować można wyraźny trend wzrostowy dla prac rozwojowych. Jest to wyraźny sygnał, że technologia VR osiągnęła już stan możliwości bezpiecznego i skutecznego wdrażania w sektorze przemysłowym.

Wraz z rozwojem sprzętu komputerowego oraz stworzeniem okularów VR, które mogą być stosowane w rozwiązaniach profesjonalnych, zaczęły pojawiać się większe możliwości wykorzystania technologii do użytku w przemyśle. Oznacza to, że sprzęt VR może współpracować przykładowo z oprogramowaniem CAD i PLM. Dodatkowo obsługa i tworzenie świata wirtualnego zostały znacznie uproszczone z biegiem lat. Urządzenia VR będące zaawansowane technologicznie, kompaktowe i w przystępnej cenie wzbudzają spore zainteresowanie na rynku. Sytuacja taka ma miejsce od roku 2011, kiedy to stworzono prototyp gogli Oculus Rift poprzez firmę Oculus VR. W obecnych czasach pojawia się coraz więcej inicjatyw wdrażających pomysły na wykorzystanie omawianej technologii. Taka sytuacja świadczy o wejściu technologii w fazę wzrostu, co zostało ukazane na wykresie analizy potencjału (rys.2), obrazującym aktualny poziom jej rozwoju.

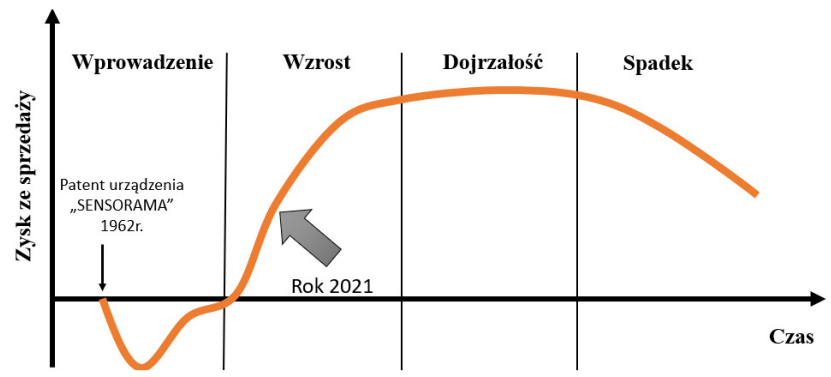

Rysunek 2. Analiza potencjału rozwoju technologii wirtualnej rzeczywistości (ogólnie)

VR zaczyna być używany jako usprawnienie aktualnie istniejących procesów w firmie. Przykładem takim jest koncern Toyota, który korzystając z systemu VR posiada możliwość przetestowania projektu produktu w świecie wirtualnym. Kompletny model jest implementowany do cyfrowego środowiska, gdzie użytkownik jest w stanie zobaczyć go w naturalnej skali. Technologia posiada również możliwość 
przetestowania produktu na wirtualnym torze, nim zostanie wyprodukowana jego fizyczna wersja.[7]

Kolejnym narzędziem służącym do oceny potencjału i możliwości wdrażania nowoczesnych rozwiązań jest analiza SWOT. Głównym celem tejże analizy jest określenie aktualnej pozycji badanego przedmiotu i jego perspektyw, a wraz z tym najlepszej strategii postępowania. Sama nazwa SWOT pochodzi od pierwszych liter słów czynników klasyfikujących możliwości danego rozwiązania: Strenghts (silne strony), Weaknesses (słabe strony), Opportunities (szanse), Threats (ryzyka). Ocena SWOT potencjału wdrożenia technologii VR została przedstawiona przez autorów w tabeli 1.

Tabela 1. Analiza SWOT dla wdrożenia technologii VR $w$ firmie

\begin{tabular}{|c|c|c|}
\hline & Silne strony $(\mathbf{S})$ & Słabe strony $(W)$ \\
\hline \multirow{5}{*}{ 趂 } & 1. Innowacyjność w branży & 1. Wysoki próg wejścia technologii \\
\hline & $\begin{array}{l}\text { 2. Uniwersalność i mnogość } \\
\text { zastosowań wewnatrz organizacji }\end{array}$ & $\begin{array}{l}\text { 2. Skomplikowany proces wiernego } \\
\text { odwzorowania działania obiektów }\end{array}$ \\
\hline & $\begin{array}{l}\text { 3. Możliwość nieograniczonego } \\
\text { rozwoju technologii zgodnie } \mathrm{z} \\
\text { potrzebami firmy }\end{array}$ & $\begin{array}{l}\text { 3. Negatywny wpływ gogli VR na } \\
\text { zdrowie użytkowników w dłuższej } \\
\text { perspektywie }\end{array}$ \\
\hline & $\begin{array}{l}\text { 4. Możliwość zbudowania efektywnego } \\
\text { marketingu z pomocą VR }\end{array}$ & $\begin{array}{l}\text { 4. Potrzeba wygospodarowania } \\
\text { bezpiecznej przestrzeni do użytkowania } \\
\text { sprzętu }\end{array}$ \\
\hline & 5. Niski koszt utrzymania technologii & 5. Wymagana wyszkolona kadra \\
\hline & Szanse (O) & Ryzyka (T) \\
\hline \multirow{6}{*}{ 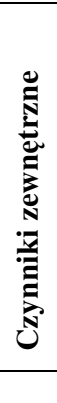 } & $\begin{array}{l}\text { 1. Możliwość wejścia na nowe rynki } \\
\text { dzięki technologii VR }\end{array}$ & $\begin{array}{l}\text { 1. Pojawienie się nowej, przełomowej } \\
\text { technologii wirtualizacji rzeczywistości }\end{array}$ \\
\hline & $\begin{array}{l}\text { 2. Budowa prestiżu firmy dzięki } \\
\text { innowacyjnym rozwiązaniom }\end{array}$ & $\begin{array}{l}\text { 2. Przyzwyczajenie konsumentów do } \\
\text { sprawdzonych technologii }\end{array}$ \\
\hline & $\begin{array}{l}\text { 3. Zdobywanie przewagi } \\
\text { konkurencyjnej w danym sektorze }\end{array}$ & 3. Brak zwrotu z inwestycji wdrożenia \\
\hline & $\begin{array}{l}\text { 4. Możliwość doskonalenia technologii } \\
\text { zgodnie z tendencją światową }\end{array}$ & $\begin{array}{l}\text { 4. Możliwość nieznalezienia właściwego } \\
\text { zastosowania }\end{array}$ \\
\hline & $\begin{array}{l}\text { 5. Społeczny wzrost zainteresowania } \\
\text { praktycznym zastosowaniem VR. }\end{array}$ & $\begin{array}{l}\text { 5. Postrzeganie wirtualnej rzeczywistości } \\
\text { jako przyczyny dehumanizacji }\end{array}$ \\
\hline & Czynniki pozytywne & Czynniki negatywne \\
\hline
\end{tabular}

Przeprowadzona analiza ma na celu ukazanie kluczowych szans i problemów stawianych przed wdrożeniem wirtualnej rzeczywistości. Każde przedsiębiorstwo planujące wprowadzenie tej technologii powinno przeprowadzić indywidualną analizę SWOT z czynnikami charakterystycznymi, ważnymi i odpowiadającymi zapotrzebowaniu organizacji. Potencjał, który na tę chwilę można obserwować będzie rósł proporcjonalnie do technologii informatycznych.

\section{Projektowanie w wirtualnej rzeczywistości}

Ze względu na stale rosnącą konkurencję, przedsiębiorstwa zobligowane są do zwiększania nakładów finansowych na wdrażanie nowoczesnych technologii i metod zarządzania. Zastosowanie technologii wirtualnej rzeczywistości w zakresie 
projektowania zakładów przemysłowych to kolejny (opcjonalny) etap w projektowaniu, konstruowaniu oraz organizowaniu ich wewnętrznej przestrzeni. Wirtualna eksploatacja przedsiębiorstwa dostarcza wsparcia i nowej jakości wiedzy w zakresie analizy funkcjonalności projektowanych rozwiązań [1].

W ramach działań ukierunkowanych na projektowanie i wytwarzanie istotne jest umiejętne przekazywanie kluczowych informacji o zaprojektowanym obiekcie potencjalnemu odbiorcy w łatwy i przejrzysty sposób [4]. W tym celu coraz częściej stosowana jest wirtualna rzeczywistość, która umożliwia prezentację produktu (obiektu, przestrzeni itd.), który technicznie nie jest jeszcze wytworzony, w formie interaktywnej wizualizacji przestrzennej [5]. Tego typu podejście - wizualizacji w postaci wirtualnej rzeczywistości - może być stosowane jako narzędzie wspierające na każdym etapie procesu projektowo - konstrukcyjno - wytwórczego.

Obiekty stosowane $\mathrm{w}$ wirtualnej rzeczywistości są modelami trójwymiarowymi rzeczywistych elementów tworzonych na podstawie nowoczesnych systemów CAD/CAE (Computer Aided Design/Engineering). W efekcie pozwala to na prowadzenie różnego rodzaju badań modelu obiektu/obiektów w warunkach rzeczywistości wirtualnej w obszarze jego/ich działania, funkcjonalności, ergonomii, poprawności montażu i demontażu, właściwego ułożenia lub rozmieszczenia, estetyki wykonania itd. [2]

W wyniku procesu projektowania wirtualnego zakładu przemysłowego (rys.3) tworzony jest model istniejącego (stworzonego na podstawie dokumentacji technicznej lub korzystając $\mathrm{z}$ istniejących skanów 3D modeli zakładu) bądź przyszłego obiektu.

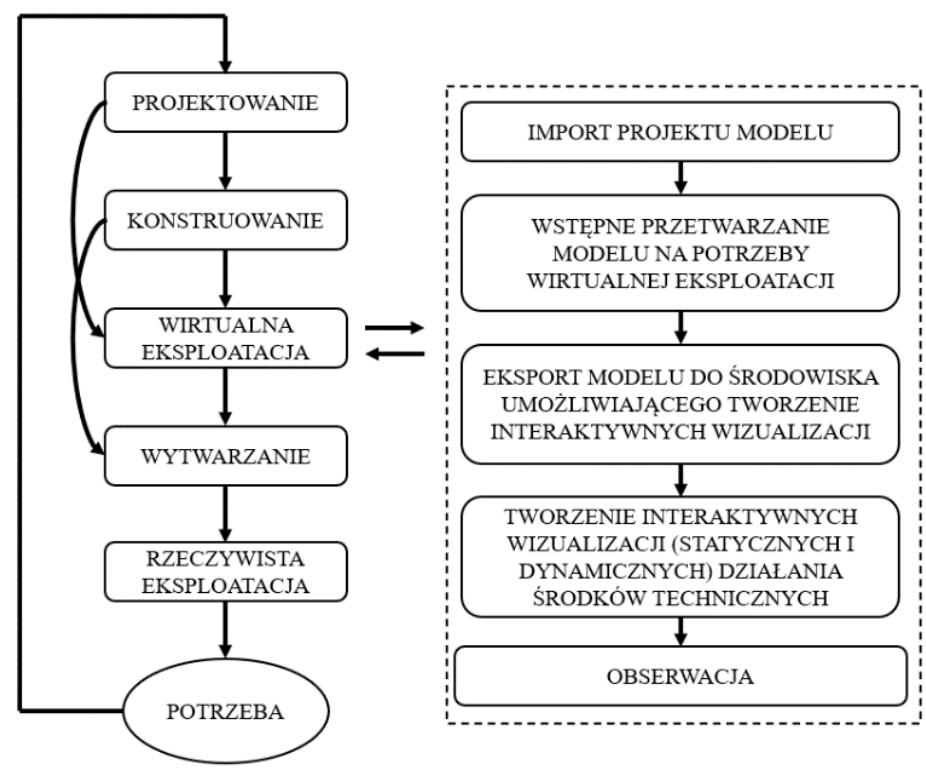

Rysunek 3. Podstawowe fazy procesu projektowo-wytwórczego z użyciem wirtualnej rzeczywistości

Ścieżka budowy wirtualnego wzorca zależy od sytuacji początkowej tworzenia projekcji oraz jego celowości (budowa, rozbudowa, modernizacja). Na etapie 
projektowania zakładu przemysłowego i jego wyposażenia (w tym organizacji przestrzeni produkcyjnej) wirtualna rzeczywistość może posłużyć jako kolejny etap procesu projektowo-konstrukcyjnego. Etap ten, rozumiany jako wirtualna eksploatacja modelu obiektu, pozwala na przeprowadzenie analizy działania, funkcjonalności, symulacji ruchów, planowania i oceny rozmieszczenia obiektów (maszyn, urządzeń technicznych, sieci ścieżek transportowych i dla pieszych), sprawdzanie ich logiki układu poprzez wirtualny spacer. [2]

Wyniki oceny interaktywnych wizualizacji symulacji działania należy traktować jako informację zwrotną w odniesieniu do procesu konstruowania obiektu przemysłowego i planowania organizacji produkcji wewnątrz. Rezultat tych działań będzie stanowić jedną z grup danych wejściowych podczas kolejnej sesji w procesie projektowo konstrukcyjnym [2]. Działania projektowe, niezależnie od skali inwestycji, są realizowane przy współudziale wielu specjalistów z różnych dziedzin nauki i wiedzy. Zastosowanie dodatkowego narzędzia w postaci wirtualnej rzeczywistości do bardziej atrakcyjnego i przystępnego sposobu przedstawienia problematyki projektowej (rys. 4) na różnych jej etapach, może spowodować szersze zrozumienie wszystkich wyzwań dla grupy specjalistów i stworzyć synergię współpracy.

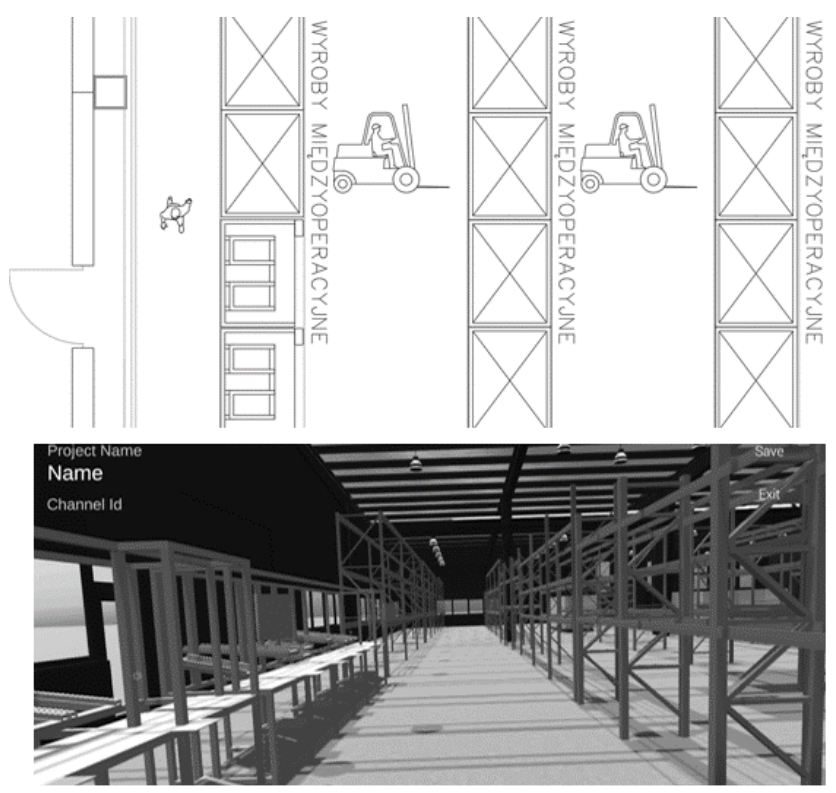

Rysunek 4. Fragment rzutu koncepcyjnego projektowanej hali produkcyjnej oraz jego odpowiednik $w$ wirtualnej rzeczywistości (Unity)

Projektowanie zakładów przemysłowych ze względu na dużą różnorodność i złożoność, dynamikę zmian w inżynierii materiałowej, wytwarzania i zarządzania przedsiębiorstwem, stanowi bardzo zaawansowaną dziedzinę projektowania w technice. Nowoczesne projektowanie wymaga znacznego wyprzedzenia teraźniejszości, toteż w kontekście przewidywanego okresu pracy zakładu (kilkadziesiąt lat) umiejętność zaprognozowania przyszłych potrzeb i związanych z nim zmian jest dziś kluczowa. Wirtualna rzeczywistość w zakresie projektowania zakładów przemysłowych pozawala również na generowanie nowych pomysłów, 
zmian w sposobie rozmieszczenia maszyn, urządzeń, regałów magazynowych, rozwiązań i udogodnień w zakresie projektowania przestrzeni roboczych, sanitarnosocjalnych, biurowych itd., poprzez możliwość zaangażowania w ten proces wielu dodatkowych osób, niekoniecznie dobrze znających się na rysunku budowlanym 2D $\mathrm{i}$ istocie samego projektowania.

\section{VR - korzyści dla użytkownika}

Postęp narzędzi projektowych wyszedł już dawno poza skalę 2D, gdzie na podstawie rysunku należało wyobrażać sobie produkt. Większość produktów jest aktualnie projektowania od samego początku w widoku 3D. Narzędziem służącym do rozwoju zakładów produkcyjnych, które łączy się z technologią VR oraz wspomnianym podejściem, jest wirtualna fabryka. Rozwiązanie to może przydać się na każdym etapie istnienia zakładu produkcyjnego, praktycznie w większości branż[6]. Posiadając zaprojektowaną wirtualną fabrykę, czyli realne odwzorowanie prawdziwego zakładu oraz okulary do wirtualnej rzeczywistości uzyskuje się możliwość obejrzenia świata wirtualnego z perspektywy pierwszej osoby. Wirtualny świat pozwala na pełną swobodę ruchów odwzorowującą naturalne poruszanie się. Nauka posługiwania się wirtualną rzeczywistością jest prosta dla osób w każdym wieku. Jest to związane $\mathrm{z}$ faktem, że widziany obraz dopasowuje się do naszych rzeczywistych ruchów. Ponadto istnieje nieskrępowana swoboda w programowaniu interakcji z wirtualnym otoczeniem, która dodatkowo poszerza możliwości tworzenia zmian i innowacji. Projektowanie i optymalizacja rozmieszczenia stanowisk produkcyjnych, urządzeń socjalno-sanitarnych i innych obiektów na terenie zakładu produkcyjnego, to pierwszy sposób wykorzystania możliwości VR. Największą zaletą tego typu podejścia $\mathrm{w}$ omawianym procesie jest fakt, że nie wymaga on użycia jakichkolwiek obiektów fizycznych. Umożliwia to porównanie ze sobą nieskończenie dużej ilości kombinacji ustawień i wybrania najbardziej optymalnego. Chcąc dokonać tego samego w świecie realnym, wymagałoby to olbrzymich nakładów pracy, czasu i kosztów. Testowanie i eksperymentowanie w świecie fizycznym wiąże się z dużym ryzykiem zakłócenia innych istniejących procesów w firmie. $\mathrm{Z}$ tego też powodu działania te najlepiej przeprowadzić w bezpiecznym środowisku wirtualnym.[7]

Dzięki wirtualnym testom uzyskuje się poczucie bezpieczeństwa w podejmowanych inwestycjach[9]. Jest to bardzo ważne, gdyż inwestując nakłady finansowe przy ograniczonych środkach budżetowych, należy mieć pewność co do zasadności ich wykorzystania. Mając przetestowane wiele wariantów, eliminuje się ryzyko potrzeby ponownej przebudowy przedsiębiorstwa. Oszczędza się w ten sposób nie tylko środki finansowe, ale również czas jaki musimy przeznaczyć na daną inwestycję, a to wszystko w konsekwencji przekłada się to na prawidłowe funkcjonowanie firmy oraz jej konkurencyjność na rynku [8]. W ramach wizualizacji i symulacji koncepcji, można tworzyć całą halę produkcyjną bądź skupić się wyłącznie na jej wybranych elementach. Oczywiście inwestycja powinna być również dobrze zrozumiana i zaakceptowana $\mathrm{z}$ pełną świadomością następstw realizowanych przedsięwzięć. Wykorzystując możliwości VR w osiągnięciu pełnej immersji w interakcjach z projektem, odbiorcy są w stanie łatwiej zrozumieć istotę podjętych działań. Mogą dokładniej ocenić wszystkie wady i zalety projektu. Każdy użytkownik, niezależnie piastowanego stanowiska, będzie mógł dokładnie zrozumieć wszystkie 
skomplikowane założenia projektu poprzez aktywne zapoznanie się z nim w świecie wirtualnym [8]. Rozwiązanie to staje się coraz częściej wykorzystywane przez przemysł, jako możliwość wybicia się ponad konkurencje. Projekty mogą być wykonywane znacznie szybciej i lepiej. Pozwala na zminimalizowanie kosztów projektu oraz przetestowanie wielu rozwiązań na wczesnym etapie realizacji, przy zachowaniu właściwego zrozumienia wad i zalet każdego aspektu. Przy aktualnych trendach rozwoju przedsiębiorstw produkcyjnych, takie podejście do rozwoju i innowacji, może być wyznacznikiem nowoczesnego podejścia do przemysłu. [10]

\section{Kierunki dalszego rozwoju VR}

Technologia VR musi być udoskonalona jeszcze o bardziej bezpieczne i intuicyjne sposoby poruszania w świecie wirtualnym. W tym celu powstają coraz bardziej zaawansowane maty, a nawet bieżnie, które pozwalają na poruszanie się w miejscu i dzięki temu poprawiają bezpieczeństwo użytkownika odciętego od świata zewnętrznego. Eliminacja tego typu ograniczeń sprzętowych usprawni wdrożenie technologii do szerszej grupy klientów. [12]

Wyjątkowo głośnym wydarzeniem w świecie VR może okazać się wprowadzenie rozwiązań graficznych obecnych już na stacjonarnych komputerach, czyli Ray Tracingu. Wydajne przetwarzanie superrealistycznej szaty graficznej w aplikacjach VR jeszcze bardziej zwiększy wspomnianą immersję. Ciekawym tematem przewijającym się ogólnoświatowych mediach technologicznych jest rozwiązanie VR All-in-Two. Procesory, z których korzystają dziś smartfony coraz częściej dysponują ogromną mocą obliczeniową, na tyle dużą, że z powodzeniom mogą stanowić bazę dla urządzeń VR. Mowa tu np. o lekkich okularach podłączanych do smartfonu, które do generowania świata VR korzystać będą z jego układu graficznego i mocy obliczeniowej. W ramach przemysłu wytwórczego i innych branż, technologia VR będzie coraz powszechniej wykorzystywana przy organizacji szkoleń, które w rzeczywistości nie będą zakłócać funkcjonowania firmy. [13]

Poziom odwzorowania hali produkcyjnej, powinien być coraz bardziej zaawansowany. Z czasem powinno być możliwe stworzenie dokładnego bliźniaka takiej hali, który mógłby odwzorować nie tylko obraz, ale również zasymulować dokładne działanie maszyn, ścieżek transportowych i innych ważnych elementów przedsiębiorstwa niezbędnych do jego prawidłowego funkcjonowania. Tak zaprojektowana hala produkcyjna byłaby w stanie ujawnić aspekty takie jak luki produkcyjne, braki efektywności kosztowej, a także sprawdzać wybrane przez nas parametry procesów technologicznych i produkcyjnych. [10]

\section{Podsumowanie}

Technologia wirtualnej rzeczywistości znajduje coraz większe zastosowanie W zakresie modelowania, wizualizacji i ocenie form przestrzennych. W ten sposób komputerowy świat 2D przestrzeni ekranu przekształca się w sterowany przez człowieka świat 3D, w którym jest integralną jego częścią. Tego rodzaju postęp techniczny pozwala wysnuć wniosek, że w obszarze interakcji człowiek-komputer zachodzi jakościowa rewolucja. Projektanci i użytkownicy wirtualnych fabryk, 
uzbrojeni w nowe doświadczenia i sposób komunikacji tworzą nowe pokolenie „mieszkańców cyberświatów”.

\section{LITERATURA}

1. ASANOWICZ A.: Systemy rzeczywistości wirtualnej $\mathrm{w}$ architekturze. „Architecturae et Artibus”, nr 4, ss. 5-12, 2012.

2. HERBUŚ K., ŚWIDER J.: Zastosowanie technologii wirtualnej rzeczywistości w projektowaniu maszyn. Modelowanie Inżynierskie, 37 (2009), 141-146.

3. LITWIN J. SZYMUSIK A. Kształcenie inżynierów na potrzeby Przemysłu 4.0: wykorzystanie symulacji w inżynierii przemysłowej.: w ŚLIWA M. CHODŹKO E. Edukacja w XXI wieku - teoria i metody badawcze Lublin 2020 124-127

4. NEUFERT E., Podręcznik projektowania architektoniczno-budowlanego, Wydawnictwo Arkady, Warszawa 2005.

5. SZYBICKI D., PIETRUŚ P.: Zastosowanie wirtualnej rzeczywistości w projektowaniu stacji zrobotyzowanych. Pomiary Automatyka Robotyka, R. 24, Nr 2/2020, 63-68.

6. Jakie są korzyści z cyfrowych bliźniaków?, https://automatykab2b.pl/tematmiesiaca/53180-cyfrowa-fabryka/strona/11-jakie-sa-korzysci-z-cyfrowychblizniakow, 7.11.2021

7. Wirtualna Fabryka - szansa dla firm prosperujących w przemyśle, https://ksiss.com/blog/wirtualna-fabryka, 7.11.2021

8. Digita Twin - Wsparcie w procesie podejmowania decyzji dotyczących przyszłych inwestycji w przedsiębiorstwie, https://ks-iss.com/blog/digital-twinwsparcie-w-procesie-podejmowania-decyzji-dotyczacych-przyszlych-inwestycjiw-przedsiebiorstwie, 7.11.2021

9. Cyfrowa fabryka wirtualna, https://ks-iss.com/uslugi/cyfrowa-fabryka-wirtualna, 7.11.2021

10. Produkcja wirtualna oraz korzyści z symulacji procesu produkcji i zachowania się wyrobów, https://www.controlengineering.pl/produkcja-wirtualna-orazkorzysci-z-symulacji-procesu-produkcji-i-zachowania-sie-wyrobow, 7.11.2021

11. Historia VR czyli jak powstawała wirtualna rzeczywistość, https://www.cyberskill.pl/historia-vr, 7.11.2021

12. Rzeczywistość rozszerzona w przemyśle, https://przemysl40.pl/index.php/2017/05/23/rzeczywistosc-rozszerzona-w-przemysle, 7.11.2021

13. Urządzenie AR noszone na głowie - do inspekcji w logistyce, https://przemyslprzyszlosci.gov.pl/urzadzenie-ar-noszone-na-glowie-i-gogle-vrdo-inspekcji-oraz-szkolen-w-logistyce/?gclid=CjOKCQjwrJOMBhCZARIs AGEd4VGw3rTFqU9LHVo3CqzvhPhy46ejWmJuu6InE3QHw5PoxWcydUGIl7U aAtqzEALw_wcB, 7.11.2021 